DEBATES 



\title{
PORTUGUÊS VERNÁCULO BRASILEIRO E A HIPÓTESE DA SEMI-CRIOULIZAÇÃO*
}

\author{
Mikael PARKVALL \\ Laura ÁLVAREZ LÓPEZ \\ Stockholms Universitet
}

\section{RESUMO}

Este trabalho discute a classificação do português vernáculo brasileiro como semi-crioulo e questiona parte da literatura sobre os semi-crioulos em geral. Apresentam-se algumas das diferenças entre o português brasileiro e as línguas crioulas e faz-se uma revisão das línguas classificadas como semicrioulos, propondo novas delimitações para este conceito.

\author{
ABSTRACT \\ proposes new delimitations for the semi-creole concept.

\section{PALAVRAS-CHAVE} \\ português brasileiro, crioulização, semi-crioulização

\section{KEY-WORDS} \\ Brazilian Portuguese, creolization, semi-creolization
}

This paper discusses the possible semi-creole status of Brazilian Vernacular Portuguese and questions some of the literature on semi-creoles in general. It presents some differences between Brazilian Vernacular Portuguese and creole languages and makes a revision of the semi-creoles. Finally, it

\section{Introdução}

O interesse pelos semi-crioulos tem aumentado durante os últimos anos, e muitos estudos têm se concentrado na análise do português vernáculo brasileiro (PVB), isto é, de diversas normas vernáculas 
(Lucchesi 1994) do português falado no Brasil. No entanto, o interesse dos estudiosos não se limita às variantes brasileiras, mas abrange outras variantes lingüísticas ligadas à expansão colonial européia, igualmente classificadas como semi-crioulos.

Questionaremos, neste artigo, parte da literatura que aborda os semi-crioulos em geral e o PVB em especial, já que esta pode estar prejudicando a crioulística ao utilizar alguns dos seus termos-chave de maneira que estes acabam perdendo a essência do seu significado.

\section{Os semi-crioulos}

Holm (1991:1) define um semi-crioulo como uma língua que passou por
"reestruturação parcial, gerando variantes que não foram com- pletamente pidginizadas e que preservam uma parte conside- rável da estrutura do superstrato (por exemplo algumas fle- xões) enquanto apresentam, igualmente, um grau notável de reestruturação" ou "influências crioulas, observadas nas va- riantes que originariamente não eram crioulos, mas que, atra- vés do contato com os crioulos, adotaram um número signifi- cativo de itens lexicais e traços estruturais crioulos".

Segundo o mesmo autor, o africâner, o inglês vernáculo afro-americano (AAVE), o espanhol não-padrão do Caribe, o português vernáculo brasileiro e o reunionês seriam exemplos de semi-crioulos ${ }^{2}$.

Entretanto, Fernández Bell \& Gilbert (s.d.) definem os semi-crioulos como
"línguas que se parecem com crioulos, que se caracterizam por terem muitos traços normalmente associados às línguas crioulas; embora mantenham uma parte considerável das fle- xões morfológicas das respectivas línguas de superstrato"3 
Esta definição compreenderia as duas feitas por Holm, visto que essas não especificam a direção do processo.

Entretanto, vários lingüistas, incluindo Mufwene (1997:60), Bartens (1998) e Thomason (1997:84), entre outros, opõem-se ao próprio conceito de semi-crioulo, argumentando que o termo só é útil para casos-limite, e que não constitui uma classe em si. Concordamos com eles, sem pensarmos, porém, que o termo careça de sentido: o conceito pode continuar sendo útil, assim como o são os termos cinza ou amanhecer, que designam fenômenos arbitrários sem protótipo.

Kaye (1990:301) afirma que não existe

"pidginização parcial ou crioulização parcial...assim como não existe gravidez parcial"'.

Isto pode parecer engraçado, mas uma comparação entre o inglês e o jamaicano ou o sranan, ou entre o francês e o reunionês ou o mauriciano, revela o contrário e, pelo menos no que diz respeito à estrutura dessas línguas, há um aumento de traços tipicamente crioulos em algumas delas (cf. Parkvall 2000b).

\section{PVB: um semi-crioulo?}

Acreditamos que o conceito de semi-crioulo é usado de maneira extremamente imprecisa e questionamos a classificação do conjunto de normas vernáculas brasileiras, ou PVB, como tal.

O português brasileiro é constituído por normas cultas e vernáculas em dois sistemas variáveis: é um sistema complicado devido à sua pluralidade, polarização e variabilidade. As normas vernáculas (Lucchesi 1994), também ditas populares, se opõem às normas cultas utilizadas em áreas urbanas por pessoas com curso superior completo (cf. Mattos e Silva 2002; Ribeiro 2002). As normas cultas representam versões faladas do português brasileiro padrão, descrito nas gramáticas normativas. Um exemplo da complexida- 
de destes sistemas é que as mudanças morfossintáticas observadas em normas faladas cultas e vernáculas não vão na mesma direção: enquanto as normas vernáculas adquirem traços da escrita, ou norma padrão, as normas cultas faladas estariam perdendo alguns traços que as caracterizam como, por exemplo, a concordância em sintagmas nominais.

Não negamos que o PVB tenha conservado um número mais elevado de traços morfológicos da língua mãe do que o são-tomense ou o sranan; isto faz parte do próprio conceito de semi-crioulo. Aliás, podemos constatar, no Brasil, mudanças lingüísticas devidas ao contato lingüístico. Em conseqüência, poderíamos dizer que, no sentido tipológico, o PVB se encontra realmente entre o português europeu padrão e um crioulo prototípico.

Contudo, parece-nos razoável exigir uma certa distância tipológica entre a língua lexificadora e o possível semi-crioulo para que o conceito seja válido (cf. De Kleine 1997:290). Propomos ainda que a distância deve constituir-se de mudanças que não se dão normalmente na evolução das línguas (quer dizer, mudanças que não surgiriam através do contato lingüístico).

Constatamos que enquanto a distância entre o PVB, inclusive as variantes rurais que mais se afastam do padrão, e o português europeu padrão é constituída por um conjunto limitado de características, a distância entre o primeiro e um crioulo prototípico é considerável. As principais características sintáticas que diferenciam o português vernáculo brasileiro da modalidade européia da língua portuguesa seriam as seguintes (cf. Lucchesi e Lobo 1996):

a) realização do sujeito lexical e redução na flexão númeropessoal do verbo (EU vejo/ NÓS fala(mos))

b) variação da concordância nominal com preferência pela marcação do plural apenas no primeiro elemento do SN (OS $\operatorname{carro}(s) / A S \operatorname{casa}(s))$ 
c) realização variável do objeto direto, ou clíticos acusativos de 3 a pessoa, com as variáveis objeto nulo/forma nominativa da 3 a pessoa (Eu vejo/Eu vejo ELE)

d) colocação dos clíticos em posição pré-verbal ( $M E$ diga uma coisa)

e) estratégias de relativização: relativa com lacuna/relativa com pronome lembrete/relativa cortadora (eu tenho uma professora que [Ø] é suecal eu tenho uma professora que ELA é suecal a professora que en falei com ELA ontem/ a professora que en falei [Ø] ontem)

f) ordem dos constituintes na oração é SVO e possibilidade de interrogativas-Q sem nenhum movimento (eu como acarajé/ você mora onde?)

g) preferência do falante brasileiro pelas formas do gerúndio quando o português escolhe a forma [a + infinitivo] (estou falando)

Embora existam diferenças estruturais básicas entre estas duas modalidades de português, como vêm defendendo vários lingüistas brasileiros (cf. Tarallo 1983; 1988; Kato 1996, Mattos e Silva 1999), as semelhanças são muitas. Assim como o português europeu padrão, o PVB possui gênero gramatical, ao contrário do sranan e do sãotomense. Assim como o português europeu padrão, o PVB possui três tipos de conjugações verbais regulares, um afixo que marca o plural, uma distinção de voz, e muitos outros traços morfológicos que não existem nesses dois crioulos. Poderíamos também expandir essa enumeração adicionando outros traços lingüísticos, ou mais línguas crioulas, mas o resultado seria o mesmo: comparado com os crioulos, o PVB se afasta muito pouco da sua língua mãe para podermos reuni-lo aos crioulos de base lexical portuguesa. 
É também interessante comparar a língua mãe do português, o latim, com as normas vernáculas brasileiras já que concluímos que a distância tipológica entre o latim e o português europeu padrão é maior do que a distância entre o último e o PVB. Houve no português uma redução do número de conjugações regulares para os verbos de quatro para três, uma substituição da distinção de três gêneros do latim por um sistema que possui dois gêneros, um abandono drástico do sistema de seis declinações morfológicas e uma redução do inventário de afixos regulares de plural de cinco para um. No que diz respeito a essas mudanças tipológicas, constatamos que mesmo as variantes brasileiras que mais se afastam do padrão continuam parecendo-se com português europeu padrão.

Podemos mencionar um exemplo: uma categoria extremamente gramaticalizada como o gênero desaparece em todas as línguas consideradas como verdadeiros pidgins ou crioulos. O sistema de gênero pode passar por uma redução (é o caso das línguas românicas e da maioria das línguas germânicas), ou até perder-se completamente (como no inglês) sem pidginização, crioulização ou mesmo semi-crioulização. Vários estudiosos do PVB têm mencionado a ausência esporádica de concordância de gênero como um dos traços mais impressionantes. Mas até hoje ninguém encontrou uma variante na qual o gênero como categoria gramatical estivesse completamente ausente. A maioria dos exemplos fornecidos apresentam uma mudança de gênero, e não uma ausência, como:

ũa abóta (um aborto) (Ferreira 1984-5:30-31)

essas coisarada bunito (Amaral 1920:70)

Comparado com o português europeu padrão o PVB pode parecer um crioulo, mas as diferenças não são espetaculares, e não precisamos de uma hipótese de crioulização prévia para explicá-las.

Por outro lado, tem-se apontado a impossibilidade de definir os crioulos a partir de bases lingüísticas, e a necessidade de fazê-lo, 
exclusivamente, a partir da sua história social (cf. Carvalho 1984:50; Chaudenson 1992:136; Corne 1995:121; de Rooij 1997:310; Huber 1995:219; Jennings 1995:63; Kapanga 1993:452; Kihm 1980:212 $)^{5}$. Embora a definição de Holm acima citada só faça referência a fatores lingüísticos, é possível invocar a história social em defesa da classificação do PVB entre os semi-crioulos. Falta saber quais os dados sócio-históricos que identificariam o PVB como um semi-crioulo. A passagem de um grande grupo de falantes de uma língua para outra não seria suficiente, já que esse argumento faria do inglês americano um semi-crioulo $(80 \%$ dos falantes dessa língua não são originários das Ilhas Britânicas). Esta proposta poderia ser igualmente válida no que diz respeito às línguas românicas e a outras variantes lingüísticas. Um exemplo interessante em relação à passagem de uma língua para outra, em grande escala e sem maiores conseqüências lingüísticas, seria a língua silozi, na Zâmbia, que surgiu através da passagem dos falantes de seluyana para o seshuto, após mais de vinte anos de domínio político de uma pequena elite de falantes de seshuto. As escassas influências de substrato encontram-se, sobretudo, no campo da fonologia, e o selozi ainda é inteligível para os falantes de seshuto (Givón 1979:11-12). Em outras palavras, a passagem rápida de uma língua de uma minoria para um grupo maior nem sempre leva à transmissão interrompida.

Supondo que quem propõe uma crioulização prévia do PVB não exija que o grupo que muda de língua seja constituído de afrodescendentes, o critério da escravatura seria o único que resta. O sistema escravocrata teria feito com que o português padrão, a língua alvo, se tornasse tão inacessível para os escravos, que a reestruturação lingüística teria sido inevitável. Mas não temos certeza de que a sociedade escravocrata tenha tido esse efeito (McWhorter 1999b; Parkvall 2000b). Aliás, ainda faltaria provar se houve realmente uma diferença no que diz respeito a acessibilidade entre a exposição dos povos do sul da Europa ao latim e a dos africanos escravizados no Brasil à língua portuguesa. 


\section{1. "Traços crioulos" no PVB?}

Os "traços crioulos" identificados até hoje no PVB aparecem também em outras línguas. Comentaremos esses traços na seção 4.

As línguas crioulas não se distinguem das não-crioulas através da presença de traços individuais, mas através da alta concentração e da combinação de certos traços. No entanto, muitos dos "traços crioulos" que aparecem no PVB são altamente variáveis, e outros, que deveriam estar presentes em uma língua que surge em contexto de contato lingüístico onde há várias línguas mutuamente ininteligíveis (como ausência completa de gênero), não têm sido encontrados.

\section{2. "Traços crioulos" no PE?}

Vários autores, como Révah (1963:447), sugeriram que o que outros percebem como crioulismos muitas vezes são arcaísmos ou variantes dialetais atualmente ou antigamente encontradas na Europa. Um exemplo é a variação entre /l/ e /r/, documentada na Europa, pelo menos em estudos diacrônicos (Williams 1946:62-63). Temos outro exemplo em Holm (1992:47), onde o autor menciona que o verbo imaginar foi sujeito a aférese no PVB (maginâ), sem considerar que formas idênticas foram levantadas no português europeu arcaico (Williams 1946:103) e moderno (Coelho 1967:164), assim como no galego moderno. Esses exemplos podem ser marginais na Europa, mas devemos levar em conta que também não são regulares em nenhuma variante do PVB. Note-se ainda que Holm, ao comparar o português europeu com o brasileiro, apresenta exemplos europeus da língua padrão, enquanto os exemplos brasileiros provêm de variantes não-padrão.

Segundo Holm (1992:37), a redução drástica na concordância de número no SN e na concordância entre sujeito e verbo são os traços mais conspícuos no PVB. Ele afirma (a despeito de Révah 1963:443) que é uma mudança de caráter morfológico e não fonológico. Concordamos com a análise de Holm, a mudança não é unicamente fonológica (cf. Mello 1996:111), mas encontramos esse mesmo fenômeno em Portugal ${ }^{6}$; Naro \& Scherre (1999) fornecem exemplos levantados em Portugal como: 
era duas, três sardinha

eu onte foi à Malbada

Lamentavelmente, o trabalho de Naro \& Scherre tem se limitado sobretudo à questão da concordância e acreditamos que, para poder demonstrar que as mudanças dependem de fatores internos, os pesquisadores deveriam levar em conta todos os fatos sintáticos característicos do PVB. A clivagem do predicado do tipo falar ele falou (Holm 1988:179, 1992:58) é perfeitamente possível em Portugal e ainda encontramos formas análogas na Península Ibérica, por exemplo no espanhol hablar habló. Construções idênticas (verbo no infinitivo + [sujeito] + verbo com flexão de tempo) estão presentes em outras línguas românicas, como as variantes não-padrão do italiano e do francês (Parkvall 2000c:90). A sintaxe desse tipo de predicados no PVB é idêntica à das estratégias européias, e só se parece vagamente com as estratégias observadas nas línguas africanas ou nos crioulos do Atlântico (cf. Byrne \& Winford 1993; Corne 1987; Lumsden \& Lefebvre 1990; Bynoe-Andriolo \& Yillah 1975; Huttar 1981:305-07; Alleyne 1980; Allsopp 1976:14-15; Hancock 1987; Mufwene 1987; Parkvall 2000c:88-93).

Outras mudanças sintáticas, como o uso da preposição em com verbos que indicam movimento como o verbo ir (Holm 1992:61), o uso de ter em vez de haver (Holm 1992:60), o uso da preposição para com os verbos dar e falar (Holm 1992:61), e a generalização do pronome relativo que (Holm 1992:59), que Holm identifica como "traços crioulos" no PVB já foram documentadas em variantes arcaicas do português europeu (cf. Mello 1996) ${ }^{7}$.

Para alguns dos traços podemos levantar as objeções acima mencionadas, mas gostaríamos de acrescentar que o uso do verbo 'ter' com o significado de 'haver' não só está presente no português padrão europeu (Mello 1998) e já aponta em João de Barros em meados do século XVI (Rosa Virgínia Mattos e Silva, comunicação pessoal), como também é comum no alemão da Baviera Es hat Schnee 'Tem 
neve', e em outras línguas como o twi, o cantonês, o groenlandês e a língua sueca de sinais.

\section{3. "Traços crioulos" ou africanismos?}

Muitos dos lingüistas que argumentam a favor da hipótese da semicrioulização utilizam o termo crioulo para denominar o que parece ser qualquer tipo de contato lingüístico. $\mathrm{O}$ traço-chave dos crioulos, que faz com que sejam diferentes de outros tipos de combinações lingüísticas, como por exemplo das línguas mistas, é que eles apresentam características que revelam uma simplificação prévia drástica - no sentido de movimento em direção ao menos marcado -, ou seja, uma transmissão interrompida (cf. Thomason \& Kaufman 1988).

Algumas características do PVB representam simplificações (cf. Mühlhäusler 1997:4, 128), mas muitos dos argumentos a favor de uma crioulização prévia no Brasil incluem traços cuja natureza mal sugere pidginização: muitos dos traços poderiam ser explicados pela influência de línguas de substrato. Gilbert (1994:1) afirma, fazendo referência a Schneider (1991), que identificou características semelhantes às das línguas crioulas no léxico do PVB. Visto que o livro de Schneider (1991) é uma compilação de itens lexicais africanos que aparecem em obras sobre a influência africana no PVB, parece-nos que, segundo Gilbert, as características crioulas e as influências de línguas de substrato seriam fenômenos equivalentes. Porém, grande número de línguas cujo léxico apresenta influências de substrato não passaram por uma transmissão interrompida ${ }^{8}$. Temos que reconhecer que influências africanas não são, por definição, traços crioulos embora, na prática, não seja possível distinguir os dois fenômenos no que diz respeito a casos específicos?.

O contato lingüístico pode afetar uma língua sem provocar um processo de crioulização - o inglês e o francês são bons exemplos disso. $\mathrm{O}$ contato pode ainda ser intensivo ao ponto de gerar novas línguas, questionando as relações genéticas. O mitchif (Bakker 1997), por exemplo, é uma língua que surgiu em um contexto de contato intensivo, mas não 
é um crioulo, visto que a sua história mal envolve simplificação (muito pelo contrário, uma gramática completa dessa língua incluiria quase todas as regras da língua francesa e da língua cree).

\section{PVB: descendente do são-tomense?}

Já notamos que Holm define o semi-crioulo não só como uma língua que passou por uma reestruturação parcial, mas que inclui igualmente variantes originariamente não-crioulas que teriam sido influenciadas por línguas pidgin ou crioulas. Ora, se o PVB, como afirma Holm $(1987,1992)$, é em parte descendente do são-tomense - justamente um crioulo - a caracterização do PVB como semi-crioulo ainda seria válida, pelo menos na teoria.

Na verdade, Holm (1987:406; 1992:62) não só sugere essa ligação, mas ainda afirma ter encontrado provas no que diz respeito à relação entre o são-tomense e o PVB; esta última língua seria filha da primeira. Para defender essa hipótese, Holm aponta um número de traços lingüísticos do PVB: a não alternância na ordem das palavras em frases interrogativas, a palatalização das alveolares implosivas (Holm 1987:414; cf. por exemplo Bhat 1978), a ausência de concordância de gênero (Holm, 1987:407) e a redução da morfologia verbal (Holm 1987:420). Visto que estes são traços muito comuns nas línguas humanas, resultaria mais difícil encontrar línguas que não possuíssem estes traços "brasileiros" que línguas nas quais eles estivessem presentes. Em outras palavras, o contato com qualquer língua, e não necessariamente com o são-tomense, poderia ter produzido os mesmos resultados (cf. Zimmermann 1999:463-64). Como veremos a seguir (seção 8), muitos destes traços podem surgir sem serem motivados por um contato lingüístico considerável.

Para sermos justos com Holm, devemos acrescentar que alguns dos traços levantados são menos insignificantes, mas por outro lado já foram documentados na Europa (negação descontínua ${ }^{10}$, alternância entre $/ 1 / \mathrm{e} / \mathrm{r} /{ }^{11}$, ter existencial ${ }^{12}$ ). Outros são duvidosos no sentido onto- 
lógico (serialização verbal ${ }^{13}$, marcadores pré-verbais de tempo, aspecto e modo $\left.^{14}\right)$, ou podem ser explicados através do contato com outras línguas e não necessariamente com o são-tomense (todos os traços mencionados neste parágrafo e mais alguns outros, como simplificação de grupos consonantais ou a preposição para indicando o objeto ${ }^{15}$ ).

Observamos que as semelhanças são definidas exclusivamente em termos de traços negativos - tanto o são-tomense quanto o PVB perderam um número de traços conservados no português europeu padrão. Sabe-se ainda que o número total de traços definidos como "marcados" é menor nos crioulos que em outras línguas. Aliás, muitas das características presentes em línguas antigas passaram por diversos processos evolutivos durante um longo período de tempo: grande parte dessas carcterísticas carece de valor comunicativo e não costuma ser encontrada em línguas crioulas. É razoável definir os crioulos, em primeiro lugar, a partir de traços que se perderam em relação às línguas de base. Entretanto, as línguas denominadas pidgins e crioulas possuem traços lingüísticos que não são encontrados nas suas línguas lexificadoras ou de substrato (McWorhter 1998, 2001, McWhorter \& Parkvall 2002). Portanto, a presença de traços idiossincráticos é considerada como evidência, e seria, portanto, mais importante do que a ausência deste tipo de traços (cf. Givón 1979:25).

Aliás, quase todos esses traços poderiam descrever crioulos e semicrioulos portugueses na Ásia, que Holm, com certeza, não definiria como descendentes do são-tomense. Um método utilizado na lingüística histórica para controlar a validade de uma afirmação sobre a relação genética entre duas línguas é considerar se a comparação teria produzido outros resultados se uma língua supostamente não relacionada tivesse substituído uma das outras duas. A partir desse critério, McWhorter (1995) e Baker (1999) conseguiram provar a inter-relação entre os crioulos do Atlântico, pois a análise não teria os mesmos resultados se eles tivessem incluído, por exemplo, o tok pisin. Holm não utiliza esse método, e os seus resultados não seriam alterados de maneira significativa se um crioulo como o papia kristang substituísse uma das línguas analisadas. 
Note-se ainda que alguns dos traços foram documentados no português europeu e podem portanto ter-se difundido independentemente da Europa em direção a São Tomé e ao Brasil. Outros fenômenos (como a alternância entre as líquidas) podem ter surgido de maneira isolada nas duas variantes lingüísticas, já que é possível que estas tenham substratos em comum.

Finalmente sabemos que grande número dos traços lingüísticos apontados não só descreve qualquer língua derivada do português, mas de fato centenas e talvez milhares de línguas que não têm nenhuma ligação histórica nem com o PVB nem com o são-tomense. A ausência de passivas e marcas de caso gramatical não deixa de ser comum nas línguas do mundo. Em resumo, não podemos dizer com certeza que qualquer um dos traços lingüísticos constatados no PVB tenha origens em São Tomé a não ser que seja um traço idiossincrático. Até hoje, ninguém conseguiu levantar dados lingüísticos específicos que provassem essa ligação ${ }^{16}$.

A despeito de Couto (1999:190-91), houve realmente uma emigração em grande escala de São Tomé para o Brasil que começou no século XVII (ou talvez já em meados do século anterior) e continuou até o século XVIII, sendo suficientemente importante para fazer com que as autoridades coloniais de São Tomé entrassem em pânico (Serafim 1993:281; Sousa 1990:251; Tenreiro 1961:71, 74, 165; Garfield 1992:123, 148, 183). Visto que, no Brasil, muitos dos imigrantes se dedicavam às plantações, e que sua fortuna dependia do trabalho dos escravos, parece-nos provável, como Holm sugere, que tenham levado os seus escravos, que estavam capacitados e tinham experiência no tipo de trabalho exigido e valiam por isso muito mais do que os boçais, recentemente adquiridos, portanto, teria sido imprudente deixá-los na ilha. Observamos, porém, que as estatísticas oficiais de exportação não mostram um tráfico organizado de São Tomé para o Brasil (Serafim 1993:233; Sousa 1990:483-93).

Falantes de são-tomense foram, provavelmente, levados para o Brasil. Embora não tenhamos certeza sobre o número, eles devem ter chegado em um ponto crucial no tempo e devem ter estado presentes 
em localidades estrategicamente importantes, e teriam, portanto, tido oportunidade de implantar a sua língua no Brasil ${ }^{17}$. Porém, a própria presença dos falantes de são-tomense no Brasil continua sendo uma hipótese, já que não temos dados lingüísticos específicos que possam confirmá-la. Supomos que a sua língua desapareceu relativamente rápido, isto devido ao fato de não termos encontrado traços incontestáveis de crioulos portugueses da África em nenhuma das variantes do PVB até hoje documentadas.

Se as marcas do são-tomense tivessem sido importantes na estrutura do PVB, deveríamos encontrar algum dialeto com artigo definido pós-nominal, interrogativas bi-morfêmicas, verbo copulativo inovador (talvez /sa/, como no são-tomense ${ }^{18}$ ), ausência total de flexões verbais, uso de partículas independentes e pré-verbais de tempo, aspecto e modo, e algumas dessas partículas teriam uma forma fonética semelhante à do são-tomense e, talvez ainda, algum pronome parecido com /iné/, que os falantes de são-tomense parecem ter introduzido no crioulo palenquero na Colômbia. Embora o PVB e o são-tomense tenham traços em comum, as semelhanças são vagas e consistem, na sua maioria, em traços que acompanham qualquer tipo de contato lingüístico em qualquer lugar - não temos nem um traço no PVB que possa derivar unicamente, ou mesmo com muita probabilidade do são-tomense - e ainda menos todo um sistema lingüístico.

\section{Influências do Suriname e de Curaçao?}

Um outro argumento utilizado por Holm a favor da crioulização prévia do português brasileiro (1989:300-01, 1992:40) é o fato de haver componentes portugueses no papiamento e no saramacca. Esses componentes, tendo sido introduzidos a partir do Brasil, provariam que um crioulo brasileiro realmente existia em meados do século XVII. Quando os portugueses reconquistaram o Brasil aos holandeses na década de 1650, muitos judeus fugiram para as colônias holandesas em Curaçao e no Suriname. Eles teriam levado, do Brasil, es- 
cravos falantes de uma língua crioula de base lexical portuguesa, o que explicaria o fato de os crioulos falados atualmente nesses lugares terem grande número de vocábulos portugueses.

A objeção mais importante a tal cenário é que, embora o léxico de origem portuguesa possa ter sido levado do Brasil para o Suriname e Curaçao, isso não é prova de que a transferência tenha acontecido através de uma língua crioula. $O$ português não-reestruturado também contém um vocabulário português, e um crioulo se afasta mais da língua lexificadora em virtude da sua gramática do que através do léxico. De fato, nenhum traço idiossincrático, seja de caráter fonológico ou sintático, de qualquer uma das variantes estudadas do PVB tem formas análogas no saramacca ou no papiamento, e há ainda traços lingüísticos que apontam o contrário, pois não são aparentemente de origem brasileira. Desta maneira, a palatalização, característica do PVB utilizada por Holm (1987:414) para provar que o PVB tem suas origens no são-tomense, está ausente no saramacca, e sugere que o input português nessa língua não seja de origem brasileira ${ }^{19}$.

Não só as provas lingüísticas são insuficientes para defender a hipótese de um possível antepassado crioulo do PVB, que teria sido levado para as regiões setentrionais da América do Sul, mas há ainda dados históricos que a contradizem. No caso do Suriname (Arends 1999; Ladhams 1999a, 1999b) e de Curaçao (Maurer 1998:198-99; Hartog 1968:132), constatamos que muitos dos imigrantes judeus chegaram diretamente da Europa, e que também os judeus "brasileiros" muitas vezes chegavam via Holanda. Isso diminui a probabilidade de a língua ter-se difundido do Brasil para o Suriname ou Curaçao.

\section{O PVB e a descrioulização}

Um dos pressupostos sobre o qual se apóia a hipótese da crioulização prévia do PVB é o de que a pressão da norma padrão teria eliminado os traços desse crioulo hipotético; aliás, só temos conhecimento de dois crioulistas, Holm (1992) e Megenney (1993) que vêem 
um crioulo em dados lingüísticos do português brasileiro contemporâneo, ou seja, do século $\mathrm{XX}^{20}$.

São poucos os dados que sugerem uma descrioulização profunda que teria marcado, de maneira drástica, a evolução de um basileto prévio em direção à língua padrão. A seguir, apresentamos os nossos argumentos contra a hipótese da descrioulização.

\subsection{Falta de provas da época colonial}

Nas narrativas de viagens e na literatura, encontramos, a partir do século XVII, provas dos precedentes das línguas crioulas contemporâneas nas ex-colônias européias do Caribe, do Oceano Índico e do Pacífico. Além de fragmentos isolados de textos, há longas descrições de um grande número de crioulos (por exemplo dos crioulos ingleses da Jamaica e do Suriname, dos crioulos franceses do Haiti, de Martinica, de Trinidad e de Maurício, e dos crioulos portugueses de Cabo Verde e da Guiné Bissau) que foram publicados antes da abolição da escravatura no Brasil. Mesmo que as línguas crioulas tivessem desaparecido nesses lugares, a chance de reconstituí-las a partir desse material relativamente rico seria boa.

Porém, no caso do Brasil ninguém parece ter levantado variantes lingüísticas brasileiras que possam ser definidas como crioulos. Já que temos testemunhos de quase todas as outras regiões onde as línguas crioulas são faladas, não seria razoável que pelo menos algum escritor em algum momento tivesse documentado um crioulo brasileiro em algum lugar, se esse fenômeno tivesse existido? Ou fazendo a pergunta de outra maneira: por que os escritores que tanto mencionavam ou citavam crioulos de outros lugares teriam evitado fazê-lo no Brasil?

Uma hipótese que poderia explicar esta falta de documentação foi levantada por Mattos e Silva (1999:27), que propõe que “o que na documentação colonial, se designa por usar a lingua geral, falar a lingua geral, saber a lingua geral" poderia estar se referindo a "um português simplificado, com interferências de línguas indígenas e também de línguas africanas". No entanto, isto é unicamente uma hipótese e não 
temos conhecimento de dados que mostrem que a denominação lingua geral não se referisse em primeiro lugar a línguas de contato das quais a língua lexificadora foi o tupi. Futuras pesquisas em arquivos, dentro e fora do Brasil, poderão talvez confirmar as hipóteses apresentadas.

\subsection{Português brasileiro na África}

Grande número de afrodescendentes emigraram do Brasil (especialmente da Bahia) para o Benim, a Nigéria e países limítrofes na África Ocidental no século XIX, e seus descendentes falam português (Krasnowolski 1987:53). No mesmo século, Schuchardt (1888:245-46) constatou que a variante lingüística desses emigrantes não diferia de maneira significativa do português brasileiro, e observadores contemporâneos (Turner 1970; Castro 1965; Braga 1969, 1970) confirmam esse fato.

As principais informantes de Castro (1965:41-56), entrevistadas na Nigéria, nasceram no Brasil em 1872 e 1877 e foram para a África em 1889. Segundo Castro, ambas falavam português brasileiro. Pode-se afirmar o mesmo dos "brasileiros" no Benim (Turner 1970:14). Como pequenas minorias, rodeadas de falantes de outras línguas (línguas que foram substratos importantes no Brasil), é pouco provável que, uma vez na África, os falantes tenham adaptado a sua linguagem na direção da norma padrão. Também não parece que eles tenham falado uma variante especialmente acroletal antes de sair do Brasil, já que os emigrantes pertenciam, sobretudo, aos estratos sociais mais baixos (Krasnowolski 1987:48) e é possível que alguns deles tivessem nascido na África.

A emigração da Bahia para a África teve lugar sobretudo na segunda metade do século XIX (Krasnowolski 1987:48, 50), mas começou mais cedo, depois do levante dos malês, uma revolta de escravos fracassada que teve lugar em Salvador em janeiro de 1835 (Reis 1987), e antes de 1875 (quando o grupo é mencionado pela primeira vez por viajantes na África), umas 3000 pessoas foram do Brasil para a África Ocidental (Manning 1982:47).

Parece-nos razoável supor que o português falado por esses grupos na África reflete a fala dos analfabetos na Bahia durante a segunda 
metade do século XIX, e talvez até o PVB de 1835. Isto é extraordinário também porque os brancos, na época, constituíam uma minoria no Brasil (24\% em 1835, 44\% em 1890), e a população branca se concentrava no sudeste enquanto os negros predominavam na Bahia (Azevedo 1950:34; Rodrigues 1965:72-73; Conrad 1972; Mussa 1991:161).

Levando em conta os dados demográficos apresentados por Mussa (1991:163) constatamos que os africanos e os afrodescendentes constituíram a maioria da população brasileira (uns 60\%) a partir do século XVII e que a disposição populacional do século XIX poderia ter dado origem a grande diversidade de variantes lingüísticas. Contudo, observamos que os descendentes de brasileiros na África Ocidental utilizam uma linguagem que não tem mais semelhanças com um crioulo do que o PVB, fato que prejudica a hipótese sobre uma descrioulização que teria acontecido de maneira extensiva no Brasil depois da abolição da escravatura.

\subsection{Uma comparação: PVB vs crioulos}

Caso um crioulo tivesse sido falado no Brasil, poderíamos questionar o seu desaparecimento. Atualmente falam-se crioulos em Louisiana, na Carolina do Sul, na Austrália e em Martinica. Embora haja diferenças entre essas ex-colônias e o Brasil, pensamos que atualmente a infra-estrutura e as facilidades educacionais não estão menos desenvolvidas em Martinica do que no Brasil, e a pressão da norma padrão, variante de prestígio nessas sociedades, assim como os incentivos para adotar a língua chamada de lexificadora podem-se comparar às da sociedade brasileira.

Aliás, vemos que em muitos países, como a Jamaica, onde a descrioulização levou a uma situação lingüística que põe em causa a classificação dos mesoletos urbanos entre os crioulos, ainda podemos encontrar falantes de basiletos em contextos rurais. Ainda assim, as pesquisas de campo realizadas no Brasil não têm levantado variantes que se afastem suficientemente do padrão para serem comparadas com basiletos, visto que o dialeto de Helvécia é considerado um caso extraordinário. 
Sabendo que há muitos povoados relativamente isolados no Brasil, e que a população em muitos desses lugares se constitui unicamente de afrodescendentes, e acrescentando que o nível educativo é baixo comparado com o dos Estados Unidos ou de Martinica - onde ainda se falam línguas crioulas - questionamos por que os crioulos brasileiros teriam desaparecido até o ponto de não podermos distinguir traços indiscutíveis dessas línguas. Uma comparação mais relevante de que a que fizemos com os Estados Unidos ou a Martinica pode se fazer com a Colômbia, na localidade onde um crioulo foi documentado, El Palenque de San Basílio: ali a língua não foi descrioulizada embora tenha existido ao lado do castelhano durante séculos (Schwegler 1998).

No Brasil temos exemplos de variantes lingüísticas afrobrasileiras nas localidades rurais de Cafundó, no estado de São Paulo, ou Bom Despacho, em Minas Gerais, onde foram encontrados registros criptoléticos do PVB, que contém um número limitado de itens lexicais de origem africana (ver Queiroz 1984; Vogt, Fry \& Gnerre 1980; Vogt \& Fry 1985; Vogt \& Fry 1996; Cunha \& Souza 1997; Petter 1998; Souza 1999). Nestes casos observa-se que os falantes desejam manifestar a sua origem africana através da linguagem, fato constatado tanto por lingüistas como por antropólogos. Já que um hipotético crioulo prévio deveria ter sido falado sobretudo pela população negra, este deveria ter sido o primeiro candidato para ser usado no sentido emblemático da linguagem, tanto nos lugares acima citados como em outros lugares. Temos também no Brasil a possibilidade de fazer uma comparação interessante com as línguas gerais (Rodrigues, 1986) que foram substituídas pela língua portuguesa durante a segunda metade do século XVIII. De fato, hoje, dois séculos e meio mais tarde, ainda podemos encontrar comunidades onde a língua geral amazônica é utilizada como meio de comunicação (Couto 1999:188-89).

A maioria dos estudiosos que propõe a hipótese da crioulização prévia sugere que a abolição da escravatura teria incentivado a extinção desses crioulos. Mas até há pouco tempo pessoas nascidas durante a escravatura ainda eram vivas, e ninguém se lembrava de ter ouvi- 
do um crioulo. O contraste reside na vitalidade relativa da língua geral, cuja regressão começou mais de um século antes da abolição.

Se o PVB realmente tivesse sido um crioulo antigamente, não haveria alguém que tivesse encontrado algum falante em algum lugar que não utilizasse, por exemplo, o gênero gramatical? Em um lugar como Helvécia, há uma certa generalização das formas masculinas, mas pidginização, na nossa interpretação do termo, envolve abandono completo de grande parte das distinções gramaticais (e definitivamente a do gênero), mais do que a generalização gradual de uma certa categoria. Não estamos dizendo que as tendências simplificadoras não se expliquem pelo contato lingüístico, mas contato lingüístico não equivale a crioulização; se fosse o caso teríamos que definir todas as línguas do mundo como crioulos ou semi-crioulos.

Em outras palavras, são poucos os traços, se ainda podemos dizer que há algum, que sugiram que um crioulo de base portuguesa tenha sobrevivido até a abolição da escravatura. Se um desses crioulos tivesse passado por um processo de descrioulização antes da abolição, como explicar o fato de o sistema de plantações ter feito com que a língua portuguesa fosse inacessível aos escravos durante o século XVII, enquanto os descendentes dos mesmos escravos que trabalharam nas mesmas plantações tenham conseguido aprender português dois séculos mais tarde?

\section{Houve um crioulo português no Brasil?}

Gostaríamos de salientar aqui que não descartamos a possibilidade de vários crioulos portugueses terem existido no Brasil (cf. Castro 1980). Mas são poucos os traços levantados até hoje, se podemos dizer que existem, que sugerem que o PVB contemporâneo seja, em parte, descendente de um tal crioulo. Assim como Tarallo (1988), acreditamos que pode ter havido um processo de crioulização, embora não existam traços lingüísticos que não possam ser explicados de outras maneiras. Mas para que uma hipótese tenha uma raison d'être, 
precisamos de um problema a ser explicado. Poderíamos dizer, com certeza, que todas as línguas do mundo têm um antecedente crioulo mais ou menos distante, mas não faz sentido assumir que houve uma crioulização prévia se não existem traços lingüísticos que requeiram esse processo drástico para serem entendidos.

Helvécia (Ferreira 1984-5; Baxter 1992; Baxter e Lucchesi 1997) é um dos lugares onde pode ter existido uma crioulização prévia. Dados levantados nessa comunidade indicam que pelo menos alguns dos escravos falavam um português realmente reduzido. Mas embora a existência de um tal crioulo seja possível, não podemos apontar traços, nas variantes atuais, que sugiram que o processo tenha ido além de certas reduções paradigmáticas moderadamente revolucionárias e altamente variáveis. Ainda assim, o dialeto de Helvécia continua sendo a forma mais parecida com um crioulo de base portuguesa até hoje documentado no Brasil. Note-se, porém, que nos dados de Baxter que indicam que há variação esporádica no que diz respeito à marcação de tempo, as formas generalizadas são as da terceira pessoa do singular do presente (como acontece normalmente nas línguas não-crioulas), e não o infinitivo, como é o caso da maioria dos crioulos do Atlântico. Isso - associado à natureza esporádica dessa fusão - sugere que outros processos, sem ser a crioulização, deixaram marcas na língua. Enquanto Holm vê um crioulo nos dados de Helvécia, Baxter (1997:281) sugere que o dialeto nunca careceu totalmente de distinções de tempo, aspecto e modo, uma característica dos pidgins não-expandidos, ou seja, os predecessores dos crioulos ${ }^{21}$.

A antiga República de Palmares é outro lugar onde o uso de um crioulo de base portuguesa pode ter existido. A língua franca da república pode ter sido o português, uma variante de português reestruturado, uma língua africana (provavelmente o quicongo e/ou o quimbundo) ${ }^{22}$ ou uma língua geral. Mattos e Silva (1999:27) diz a respeito das línguas gerais do Brasil que entre essas variantes

“originadas de línguas indígenas do tronco tupi, podem-se idealizar varia- 
das situações com maior ou menor marca das línguas em contato, no caso, o português e a(s) língua(s) indígena(s) e também línguas africanas".

Note-se ainda que quando o governo colonial negociava com os quilombolas, utilizavam-se intérpretes (Freitas 1984:42), o que não teria sido preciso se os quilombolas falassem português. Mas os intérpretes não teriam sido necessários se os quilombolas falassem uma variante de português reestruturado, que, mesmo que não fosse inteligível com a língua portuguesa, teria sido reconhecida pelas autoridades coloniais que deveriam ter sido expostas a essa variante lingüística anteriormente. Outro fato que indica que o português não era falado pelos quilombolas é que a maioria dos primeiros quilombolas tinham nascido na África (Péret 1988:45). Os portugueses também conheciam as línguas gerais e acreditamos, portanto, que a linguagem utilizada nessa comunidade deve ter sido baseada em várias línguas africanas, ou uma criação da comunidade com vocabulário português.

Embora alguns fragmentos dispersos de provas que documentam a linguagem dos palmarinos certamente sejam sugestivos, não temos dados suficientes para provar nada, e ainda menos para provar que se falava um crioulo ou um pidgin de base portuguesa nas plantações da Bahia ou de Pernambuco.

\section{A reestruturação do PVB}

$\mathrm{Na}$ Europa, várias línguas perderam a sua complexidade morfológica de outrora, muitas vezes como resultado de contato lingüístico. Para o inglês e o francês, que têm mais marcas de contato lingüístico do que muitas das suas línguas vizinhas, a crioulização foi realmente proposta como um fator relevante. No entanto, atualmente, poucas pessoas sustentam a hipótese da relação entre a crioulização e a evolução dessas duas línguas.

Gostaríamos, no entanto, de utilizar outra língua para ilustrarmos como uma reestruturação que não difere muito da atestada no PVB 
pode ter lugar mesmo sem contato lingüístico extenso. $\mathrm{O}$ sueco (idioma que escolhemos simplesmente por ser esta a primeira língua de um dos autores, mas poderíamos chegar às mesmas conclusões utilizando muitas outras línguas), é uma língua que não passou por formas extremas de contato lingüístico. Durante os últimos 800 anos, os seus falantes reduziram o sistema de gênero de três a dois gêneros gramaticais, deixaram de usar as flexões de caso para o acusativo e o dativo, abandonaram totalmente os paradigmas do subjuntivo e do condicional, deixaram de marcar a concordância de pessoa e número nos verbos (isso fez com que o número de formas nos paradigmas que restam tenha sido reduzido de seis a um) ${ }^{23}$.

A ordem das palavras estabilizou-se como SVO cum V2, substituindo a ordem anterior que era SOV, e os pronomes de sujeito tornaram-se obrigatórios. $\mathrm{Na}$ fonologia, as fricativas interdentais $/ \theta$, ठ/ foram substituídas pelas equivalentes dentais $/ \mathrm{t}, \mathrm{d} /$, e constatamos a palatalização das implosivas que precedem as vogais altas anteriores, à semelhança do PVB. Alguns dialetos abandonaram as vogais anteriores arredondadas.

O processo levou aproximadamente três séculos mais do que o período de formação do PVB, mas as reduções não são menos radicais do que as apresentadas na maioria das variantes do PVB. Sem dúvida, ninguém afirmaria que este é um fato a ser considerado como "provas abundantes" para demonstrar que o sueco é descendente do são-tomense. O sueco não é uma língua de contato e, portanto, nunca poderia ser classificado na mesma categoria que os semi-crioulos, nem mesmo pelos mais fervorosos defensores de uma hipótese de semi-crioulização no Brasil.

Outra variante ultramarina de uma língua colonial européia, o francês de Missouri, não tem sido muito utilizada na argumentação moderna a respeito dos semi-crioulos, mas tem se afirmado (ver Dorrance 1935:47 e Thogmartin 1979:115) que esta língua teria sido altamente influenciada por um crioulo (o haitiano), e esse processo seria semelhante ao sugerido por Holm para o PVB. A comparação torna-se relevante e interessante por várias razões, sobretudo porque o próprio Holm 
(1989:391), no seu impressionante levantamento de línguas crioulas, rejeita a idéia de que a reestruturação do francês de Missouri poderia ser explicada através da influência do haitiano. $\mathrm{O}$ autor afirma que a reestruturação do francês de Missouri se deve mais a uma evolução interna do que ao contato lingǘstico. Embora o contato possa ser um fator relevante, acreditamos que Holm esteja certo ao não classificar o francês de Missouri como um semi-crioulo, mas o que achamos interessante é a simplificação deste não ser menos marcada do que a do PVB. Muito pelo contrário, a tipologia do francês de Missouri se encontra tão perto, no sentido tipológico, do haitiano quanto o PVB, ou até o dialeto de Helvécia, em relação ao são-tomense.

\section{Revisão dos semi-crioulos}

Nada prova que algum dos cinco semi-crioulos "clássicos" cumpra os primeiros critérios de Holm, ou seja, que tenham um antecedente crioulo. Por outro lado, todos eles passaram por uma reestruturação, se bem que menos radical que a dos próprios crioulos. Mas toda língua muda com o tempo, seja a mudança devida a contato lingüístico ou não. $O$ que seria necessário para darmos uma definição útil ao termo é uma especificação para indicar o quanto estas reestruturações devem abranger (e quais das mudanças a serem consideradas como "simplificações", assim como até que ponto as mudanças foram causadas pelo contato e quanto tempo levaram). Se não chegarmos a um acordo nesses pontos, qualquer língua poderia ser classificada como semi-crioulo, e o conceito se tornaria inútil.

Lamentavelmente, parece que conceitos do tipo semi-crioulo por definição são indefiníveis. Do ponto de vista tipológico, a passagem de uma língua que não é um crioulo via semi-crioulo a crioulo não é nítida. Os extremos podem ser definidos em termos de protótipos (McWhorter 1998; McWhorter \& Parkvall 1999), onde a maioria das línguas se encontra entre os extremos 'crioulo' e 'não-crioulo'. Contudo, seria inútil utilizar a etiqueta de semi-crioulos para todas essas línguas. Nem o 
termo 'crioulo' nem 'semi-crioulo' ganhariam sentido se pudessem aplicar-se na definição de um grupo de línguas grande demais, já que perderiam grande parte do seu significado. Mais cedo ou mais tarde, um empobrecimento da terminologia da crioulística arrisca prejudicar os estudos das línguas de contato como tais. Assim como uma língua com marcadores de tempo, aspecto e modo que aparecem como partículas livres, ou uma variante lingüística sem verbo copulativo, não são necessariamente crioulos, uma língua que perdeu parte da concordância de pessoa, gênero e número, não deveria ser classificada automaticamente como semi-crioulo. Em analogia com o inglês vernáculo afroamericano e o espanhol não-padrão do Caribe, o PVB tem reduzido a sua morfologia se comparado com a sua língua-mãe européia, mas a extensão desta redução não é nada atordoante.

Duas das línguas classificadas por Holm como semi-crioulas - o africâner e o reunionês - parecem ter mais traços semelhantes aos das línguas crioulas que o PVB. Mesmo que seja impossível chegar a um acordo em relação a um protótipo para os semi-crioulos, acreditamos que essas duas línguas estão mais perto do que consideramos um semi-crioulo típico.

Os traços parecidos com os dos crioulos podem até não ser mais abundantes no reunionês ou no africâner do que no PVB, mas os dois primeiros constituem sistemas lingüísticos estáveis onde esses traços são partes integrais. No PVB, pelo contrário, muitos dos traços crioulos são marginais, e é só consultando e combinando um grande número de fontes que podemos incluir um grande número desses traços. No caso do africâner e do reunionês, uma observação superficial é suficiente para revelar um número razoável de traços semelhantes aos dos crioulos.

Em vez de expandir o conceito de semi-crioulo em direção aos acroletos, como o fazem Holm e outros pesquisadores, sugerimos que se faça o contrário - entrar no domínio das línguas que tradicionalmente têm sido denominadas de crioulos. Seria, neste caso, possível incluir as variantes de Barlavento dos dialetos caboverdianos, como 
foram descritas por Almada (1961) e Cardoso (1989) por exemplo. Nessas, o verbo copulativo /ser/, não é flexionado para pessoa ou número, mas possui, pelo contrário, quase todas as formas encontradas no português, incluindo formas como /e, era, for, fos, foj, sid/ e /sind/ (Cardoso 1989:54). Outros auxiliares são igualmente flexionados (Cardoso 1989:57).

A nossa proposta seria igualmente válida no que diz respeito aos etnoletos brancos do crioulo francês da Louisiana, descritos em Neumann (1983) e Calvet (1996). O crioulo alemão Unserdeutsch, com ser um verbo copulativo flexionado para pessoa e tempo, e uma estratégia de apassivar totalmente conservada (Volker 1989), pode também ser um candidato à classificação como semi-crioulo.

Uma característica dos crioulos é que o verbo copulativo da língua lexificadora se perde. O fato de o PVB não só conservar o verbo copulativo junto com o de as formas supletivas e as flexões serem baseadas em distinções de pessoa, parece-nos praticamente incompatível com os conceitos crioulo e transmissão interrompida.

Outras línguas que parecem pertencer à categoria dos semicrioulos são o kituba, o lingala e o shaba suaíle (cf. McWhorter 1999a). Aliás, seria razoável incluirmos os mesoletos (superiores) do Caribe anglófono, inclusive o basileto de Barbados, e talvez até o basileto da Trinidad no grupo dos semi-crioulos, assim como talvez algumas das variantes de crioulos portugueses da Ásia. As variantes lingüísticas das ilhas Pitcairn e Norfolk poderiam também unir-se a esta categoria. Evidentemente, a enumeração acima feita é impressionística, visto que os dados disponíveis sobre algumas das variantes mencionadas são limitados. Não tentaremos dar uma definição exata para o conceito de semi-crioulo, especialmente depois do escândalo que foi a resposta a uma tentativa recente de definir crioulo (McWhorter 1998; cf. Discussões na lista CreoLIST em agosto de 1999). Porém, propomos que as línguas que se situam aproximadamente entre 0 e 25 em Parkvall (2000b) talvez possam ser classificadas como semi-crioulos ${ }^{24}$. 


\section{Conclusões}

Como vimos, muitos dos fatores que separam o PVB do português europeu padrão podem ser explicados pelos traços relevantes presentes nos dialetos europeus do século XVI, ou através da evolução interna. No entanto o fato de estes dois fatores possivelmente serem responsáveis por certos aspectos do PVB não quer dizer que seja necessariamente assim. Mesmo sendo difícil demonstrá-lo, gostaríamos de salientar que não é nosso objetivo negar que o contato lingüístico seja um dos fatores principais na evolução do português brasileiro. Mas não existem estudos que demonstrem inequivocamente que as línguas faladas pelos antepassados dos afrobrasileiros tenham deixado traços morfológicos ou sintáticos no PVB que possam ser atribuídos a uma única língua ou mesmo família lingüística. Nem as línguas kwa, nem as bantas, ou qualquer outro possível substrato como iorubá ou são-tomense deixaram traços morfológicos ou sintáticos identificáveis em variantes até hoje documentadas do PVB. Acreditamos, porém, que termos específicos e algumas expressões estão sendo importados diretamente das línguas africanas (sobretudo do iorubá) por comunidades que procuram resgatar partes da herança cultural africana (cf. Álvarez 2004). Tanto quanto sabemos, ninguém observou traços estáveis no PVB decorrentes de um processo de pidginização.

Muitos têm procurado desesperadamente encontrar um crioulo no Brasil para poder confirmar a relação entre a crioulização e o desequilíbrio demográfico associado à escravatura. Ao perceberem que a realidade não confirma a teoria, alguns autores tentam adaptar a terminologia para incluir as variantes lingüísticas que não cabem na teoria atual, em vez de rever as hipóteses. Reconstruir a linguagem através da história é arriscado (sobretudo quando publicações recentes no âmbito da crioulística têm questionado as relações entre demografia e reestruturação ${ }^{25}$ ), em particular dado que sabemos muito pouco sobre as circunstâncias demográficas e sócio-históricas no Brasile. 
Às vezes, os defensores da hipótese da crioulização prévia recorrem ao bom senso quando os dados empíricos não confirmam suas afirmações. Guy (1981:309 citado em Tarallo 1988:138) pergunta "how could it [PVB] possibly have avoided creolization?", e, Gilbert (1994:6) afirma que "it would be absolutely astonishing" se um "simplified (maybe pidginized) Portuguese” não tivesse sido a língua franca do Brasil. Reconstituir a fala a partir de dados que nunca foram verificados pode fazer sentido se a reconstituição contribui para o entendimento de fenômenos que não podem ser explicados de outra maneira. Esse não é, porém, o caso do PVB.

Vimos que um semi-crioulo tem sido definido como uma língua que foi influenciada por um crioulo ou que tem traços crioulizantes que surgiram de uma transmissão parcialmente interrompida. Mostramos aqui que nenhum dos traços verificados no PVB - nem na sua forma atual, nem no século XIX - testemunham a favor da hipótese da semi-crioulização. Quanto à transmissão interrompida, é óbvio que as variantes brasileiras mais distantes do padrão foram ligeiramente reestruturadas, o que se deve, sem dúvida, ao contato lingüístico. Porém, o grau de reestruturação é muito moderado para podermos classificar essas variantes como 'semi-crioulos' e ainda menos como 'crioulos', que é o termo utilizado por Holm (1992) e Megenney (1993) para designar o dialeto de Helvécia.

De certa maneira, o PVB pode até ser um intermediário entre o português europeu padrão e um verdadeiro crioulo, mas está relativamente perto das suas origens portuguesas do século XVI e muito longe do saramacca, do negerhollands, do bislama, do tayo ou qualquer outro crioulo para poder ser classificado como tal. Quando um habitante da Ilha de Itaparica diz que mora entre Salvador e o Rio de Janeiro, não mente, mas não fornece informações relevantes a alguém que deseja visitá-lo. Normalmente, o Rio não seria utilizado como ponto de referência a não ser que a pessoa morasse no máximo a poucas centenas de quilômetros dessa cidade. Da mesma maneira, não é mentira dizer que o PVB se encontra tipologicamente entre o 
são-tomense e o português europeu padrão, mas isso é uma afirmação de pouco interesse para os pesquisadores.

Do nosso ponto de vista, uma questão bem mais interessante seria: por que não encontramos traços indisputáveis de crioulos de base portuguesa no Brasil embora haja analogias históricas óbvias com outros territórios de fala crioula. Pelo menos poderíamos esperar encontrar algo parecido com o gullah basiletal. Se tentássemos encontrar uma resposta a essa pergunta, acreditamos que esta enriqueceria os estudos das línguas de contato.

Recebido em

\section{Referências Bibliográficas}

ALKMIM, T. M. (2002) Para a história do português brasileiro. Volume III: Novos Estudos. São Paulo: Humanitas.

ALLEYNE, M. (1980) Comparative Afro-American. Ann Arbor: Karoma.

ALLSOPP, R. (1976) “The Case for Afrogenesis”. Comunicação apresentada na Conferência da Society for Caribbean Linguistics, University of Guyana, agosto de 1976.

ALMADA, M. D. (1961) Cabo Verde. Contribuição para o estudo do dialecto falado no seu arquipélago. Lisboa: Junta de Investigação do Ultramar.

ÁlVAREZ LÓPEZ, L. (2004) A língua de Camões com Iemanjá. Forma e funções da linguagem do candomblé. Tese de doutorado, Universidade de Estocolmo.

AMARAL, A. (1982) O dialeto caipira: gramática, vocabulário. 4a ed. São Paulo: Editora Hucitec.

ANDRADE, E. d' \& A. KIHM (eds.) (1992) Actas do colóquio sobre crioulos de base lexical portuguesa. Lisboa: Colibri.

ARENDS, J. (1999) "The origin of the Portuguese element in the 
Surinam Creoles". In HUBER \& PARKVALL (eds.). (195-208). AZEVEDO, F. de (1950) Brazilian Culture. An introduction to the study of culture in Brazil. New York: The Macmillan Co.

BAKER, P. (1999) "Investigating the origin and diffusion of shared features among the Atlantic English Creoles". In BAKER, P. \& A. BRUYN (eds.) St. Kitts and the Atlantic Creoles. London:Westminster University Press. (315-64).

BAKER, P. (ed.) (1995) From contact to creole and beyond. London: University of Westminster Press.

BAKKER, P. (1997) A language of our own. The Genesis of Michif, the Mixed Cree-French Language of the Canadian Métis. Oxford: Oxford University Press.

BARBOT, J. (1732) "A Description of the Coasts of North and South Guinea”. In Messrs. CHURCHILL (eds.). A Collection of Voyages. London: Thomas Osborne.

BARTENS, A. (1998) "Existe-t-il un modèle de semi-créolisation qu'on puisse déceler à partir des systèmes verbaux du portugais brésilien vernaculaire, de l'espagnol caraïbéen vernaculaire, du réunionnais, de l'afrikaans et de l'anglais afro-américain vernaculaire?". Comunicação apresentada na conferência Degrees of Restructuring in Creole languages, Regensburg, junho de 1998.

BAXTER, A. (1997) "Creole-like features in the verb system of an Afro-Brazilian variety of Portuguese”. In SPEARS \& WINFORD (eds.). (265-88).

BAXTER, A. (1992) "A contribuição das comunidades afro-brasileiras isoladas para o debate sobre a crioulização prévia: um exemplo do estado da Bahia". In ANDRADE \& KIHM (eds.) (7-35).

BAXTER, A. \& D. LUCCHESI (1997) "A relevância dos processos de pidginização e crioulização na formação da língua portuguesa no Brasil”. Estudos Lingüisticos e Literários 19 (65-84).

BHAT, D. N. S. (1978) “A General Study of Palatalization”. In GREENBERG, J. (ed.). Universals of Human Language, vol 2. Stanford: Stanford University Press. (47-92). 
BRAGA, J. S. (1969) "Contribuição ao estudo da língua portuguesa no Daomé”. Afro-Ásia 8-9 (21-28).

BRAGA, J. S. (1970) "Anciens esclaves brésiliens au Dahomey. Contribution à l'étude de la langue portugaise au Dahomey". Études dahoméennes 17 (91-98).

BYNOE-ANDRIOLO, E. \& S. YILLAH (1975) "Predicate Clefting in Afro-European Creoles". Obio State Working Papers in Linguistics 20 (234-39).

BYRNE, F. \& D. WINFORD (eds.) (1993) Focus and grammatical relations in creole languages. Amsterdam \& Philadelphia: John Benjamins. CALVET, L.-J. (1996) 'Les 'Edwiniens' et leur langue: sentiments et attitudes linguistiques dans une communauté créolophone blanche de Louisiane". Revue québécoise de linguistique théorique et appliquée 13 (950).

CARDOSO, E. A. (1989) O crioulo da ilha de São Nicolau de Cabo Verde. Praia: Ministério da Educação.

CARVALHO, J. H. de (1984) Estudos Linguísticos 1. Coimbra: Coimbra Editora.

CASTRO, Y. Pessoa de (1965) "Notícia de uma pesquisa em África". Afro-Ásia 1 (41-56).

CASTRO, Y. Pessoa de (1976) De l'integration des apports africains dans les parlers de Babia au Brésil. Tese de doutorado (2 tomos), Université Nationale du Zaïre.

CASTRO, Y. Pessoa de (1980) Os falares africanos na interação social do Brasil colônia. Salvador: Centro de Estudos Baianos/UFBA.

CASTRO, Y. Pessoa de (2001) Falares africanos na Babia. Um vocabulário afro-brasileiro. Rio de Janeiro: Topbooks.

CHAUDENSON, R. (1992) Des îles, des hommes, des langues. Essai sur la créolisation linguistique et culturelle. Paris: l'Harmattan.

COELHO, A. (1967) Estudos Lingüísticos Crioulos. Lisboa: Academia Internacional de Cultura Portuguesa.

CONRAD, R. (1972) The Destruction of Brazilian Slavery. Berkeley, Los Angeles, London: University of California Press. 
CORNE, C. (1987) "Verb Fronting in Creole: Transmission or Bioprogram?”. In GILBERT (ed) (93-112).

CORNE, C. (1995) "A contact-induced and vernacularized language: how Melanesian is Tayo?”. In BAKER (ed.). (121-48).

COUTO, H. H. do (1999) "The question of (prior) creolization in Brazil". In HUBER \& PARKVALL (eds.). (177-94).

CUNHA, A. S. A. \& SOUZA, A. C. S. (1997) "A variação da concordância em gênero na linguagem do Cafundó". Estudos Lingüisticos. Anais de Seminários do GEL XXVI (Grupo de Estudos Lingüísticos de São Paulo). Trabalhos apresentados no XLIV Seminário/1996 - UNITAU - Taubaté -SP. (134-40).

DE KLEINE, C. (1997) "The verb phrase in Afrikaans: Evidence of creolization?”. In SPEARS \& WINFORD (eds.). (289-307).

DE ROOIJ, V. (1997) "Shaba Swahili: Partial creolization due to second language learning and substrate pressure". In SPEARS \& WINFORD (eds.). (309-39).

DORRANCE, W. A. (1935) The survival of French in the old district of Ste-Geneviève. Columbia: University of Missouri.

FERNÁNDEZ BELL, M. R. \& G. Gilbert (s. d.) "Glossary of terms related to the study of pidgin and creole languages". Disponível na Internet via WWW. URL: http://www.siu.edu/departments/cola/ ling/

glsintro.htm. Consultado em 24 de 09 de 1999.

FERREIRA, C. da Silveira (1984-5) "Remanescentes de um falar crioulo brasileiro (Helvécia - Bahia - Brasil)". Revista Lusitana 5 (21-34). FREITAS, D. (1984) Palmares: a guerra dos escravos. 5a ed. Porto Alegre: Mercado Aberto.

GARFIELD, R. (1992) A History of São Tomé Island, 1470-1655. The key to Guinea. San Fransisco: Mellen Research University Press. GILBERT, G. (1994) "Convergence in Creolization: The Case of Popular Brazilian Portuguese". Comunicação apresentada no $10^{\text {th }} \mathrm{Bi}$ ennial Meeting da Society for Caribbean Linguistics, Georgetown, Guyana, agosto de 1994. 
GILBERT, G. (ed.) (1987) Pidgin and Creole Languages: Essays in Memory of John E. Reinecke. Honolulu: University of Hawaii Press. GIVÓN, T. (1979) "Prolegomena to any sane creology". In HANCOCK, I., E. POLOMÉ, M. GOODMAN \& B. HEINE (eds.). Readings in Creole Studies. Ghent: Story-Scientia. (3-35).

GUY, G. R. (1981) Linguistic variation in Brazilian Portuguese: aspects of the phonology, syntax and language history. Tese de doutorado, University of Pennsylvania.

HANCOCK, I. (1987) "A Preliminary Classification of the Anglophone Atlantic Creoles, with Syntactic Data from Thirty-Three Representative Dialects”. In GILBERT (ed). (264-333).

HARTOG, J. (1968) Curaçao. Oranjestad: De Wit. HOLM, J. (1987) "Creole Influence on Popular Brazilian Portuguese”. In GILBERT (ed.). (406-29).

HOLM, J. (1988) Pidgins and Creoles, vol. 1: Theory and Structure. Cambridge: Cambridge University Press.

HOLM, J. (1989) Pidgins and Creoles, vol. 2: Reference Survey. Cambridge: Cambridge University Press.

HOLM, J. (1991) "American Black English and Afrikaans: two Germanic semicreoles". Comunicação apresentada no encontro da SPCL, Chicago.

HOLM, J. (1992) "Popular Brazilian Portuguese: A semi-creole". In ANDRADE \& KIHM (eds.). (37-66).

HOLM, J., G. LORENZINO \& H. MELLO (1999) "Differing degrees of restructuring in two vernaculars: Caribbean Spanish and Brazilian Portuguese". Comunicação apresentada no Coloquio sobre Crioulos de Base Lexical Portuguesa, Lisboa, abril de 1999.

HUBER, M. \& M. PARKVALL (eds.) (1999): Spreading the Word. London: Westminster University Press.

HUBER, M. (1995) "Ghanaian Pidgin English: an overview". English World-Wide 16 (215-49).

HUTTAR, G. (1981) "Some Kwa-Like Features of Djuka Syntax". Studies in African Linguistics 12 (291-323). 
JENNINGS, W. (1995) "Saint-Christophe: site of the first French Creole”. In BAKER (ed.). (63-80).

KAPANGA, A. M. (1993) "Shaba Swahili and the process of linguistic contact”. In BYRNE, F. \& J. HOLM (eds.). Atlantic meets Pacific: A Global view of Creolization. Amsterdam \& Philadelphia. John Benjamins. (441-58).

KATO, M. A. (1994) "Português brasileiro falado: aquisição em contexto de mudança lingüística”. In DUARTE, I. \& I. LEIRIA (eds.). Actas do Congresso Internacional sobre o português (Lisboa, 11-15 de Abril de 1994), Volume II, Lisboa: Edições Colibri/APL, junho de 1996. (209-37).

KAYE, A. S. (1990) "Observations on pidginistics and creolistics". Semiotica 78 (285-348).

KIHM, A. (1980) "Is there anything like decreolization? Some ongoing changes in Bissau Creole". York Papers in Linguistics 11 (203-14). KRASNOWOLSKI, A. (1987) Les Afro-Brésiliens dans les processus de changement de la Côte des Esclaves. Wroclaw: Zaklad Narodowy im Ossolinskich.

LADHAMS, J. (1999a) "The Pernambuco connection? An examination of the nature and origin of the Portuguese elements in the Surinam Creoles". In HUBER \& PARKVALL (eds.). (209-40).

LADHAMS, J. (1999b) "Response to Norval Smith". In HUBER \& PARKVALL (eds.). (299-304).

LUCCHESI, D. (1994) "Variação e norma: elementos para uma caracterização sociolingüística do português do Brasil.” Revista Internacional de Lingua Portuguesa 12 (17-28).

LUCCHESI, D. \& T. LOBO (1996) "Aspectos da sintaxe do português brasileiro”. In FARIA, I. H., PEDRO E. R., DUARTE, I., GOUVEIA, C. A. M. Introdução à lingüistica geral e portuguesa. Lisboa: Editorial Caminho, SA. (303-11).

LUMSDEN, J. \& C. LEFEBVRE (1990) "Predicate-Cleft constructions and Why They Aren't What You Might Think". Linguistics 28 (4: 761-82). 
MANNING, P. (1982) Slavery, colonialism and economic growth in Dahomey, 1640-1960. Cambridge: Cambridge University Press.

MAURER, P. (1998) "El papiamentu de Curazao". In PERL, M. \& A. SCHWEGLER (eds.) (1998) América negra: panorámica actual de los estudios lingüisticos sobre variedades hispanas, portuguesas y criollas. Frankfurt-am-Main \& Madrid: Vervuert/Iberoamericana. (139-218).

MATTOS E SILVA, R.V., (1999) “Uma compreensão histórica do português brasileiro: velhos problemas revistados". Confêrencia para Concurso Público para classe de Professor Titular, UFBA, Instituto de Letras, Dept de Letras Vernáculas. Setembro de 1999.

MATTOS E SILVA, R. V. (2002) "Para a história do português culto e popular brasileiro:velhos problemas revistados". In ALKMIM, T: M. (org.). (443-64).

MCKINNEY, H. (1982) "Serial verbs in a nostandard Brazilian dialect: Possible creolization”. Comunicação apresentada no encontro da American Association of Teachers of Spanish and Portuguese, New Orleans.

MCWHORTER, J. \& M. PARKVALL (1999) "Pas tout à fait du français: Une étude créole". Comunicação apresentada no $9 e$ Colloque International des Études Créoles, Aix-en-Provence, junho de 1999.

MCWHORTER, J. (1995) "Sisters under the skin: A case for genetic relationship betwen the Atlantic English-based Creoles". Journal of Pidgin and Creole Languages 10 (1: 289-333).

MCWHORTER, J. (1998) "Identifying the Creole Prototype. Vindicating a typological class". Language 74 (4: 788-818).

MCWHORTER, J. (1999a) "A Creole by any other name: streamlining the terminology". In HUBER \& PARKVALL (eds.). (5-28).

MCWHORTER, J. (1999b) "The Afrogenesis hypothesis of plantation Creole origin". In HUBER \& PARKVALL (eds.). (111-52).

MCWHORTER, J. (2001) “'The World's Simplest Grammars are Creole Grammars”. Linguistic Typology 5 (3-4: 125-56).

MCWHORTER, J. \& M. PARKVALL (2002) "Pas tout à fait du français: une étude créole”. Études Créoles 25 (1:179-231). 
MEGENNEY, W. (1993) "Helvecian Portuguese: Vernacular dialect or true Creole?" Journal of Pidgin and Creole Languages 8 (2: 237-40). MELLO, H. (1996) The genesis and development of Brazilian Vernacular Portugueuse. Tese de doutorado, City University of New York. MELLO, H. (1998) "On the genesis of Brazilian Vernacular Portuguese”. Comunicação apresentada no encontro da SPCL, Nova Iorque, janeiro de 1998.

MELO, G. C. de (1946) A língua do Brasil. Rio de Janeiro: Livraria Agir Editora.

MUFWENE, S. (1987) "An Issue on Predicate-Clefting: Evidence from Atlantic creoles and African languages". In MAURER, P. \& T. STOLZ (eds.). Varia Creolica. Bochum: Studienverlag Dr. N. Rockmeyer. (71-89).

MUFWENE, S. (1997) "Jargons, pidgins, creoles, and koinés: what are they?”. In SPEARS \& WINFORD (eds.). (35-70).

MÜHLHÄUSLER, P. (1997) Pidgin and Creole Linguistics. Expanded and revised edition. London: University of Westminster Press. MUSSA, a. (1991) O papel das línguas africanas na bistória do português do Brasil. Dissertação de mestrado, Universidade Federal do Rio de Janeiro.

NARO, A. J. \& M. M. P. Scherre (1999) "Variable concord in Portuguese: the situation in Brazil and Portugal". In MCWHORTER, J. (ed.). In Language change and language contact in pidgins and creoles. Amsterdam \& Philadelphia: John Benjamins. (235-55).

NEUMANN, I. (1983) "Le créole des blancs en Louisiane". Études Créoles 6 (1-2: 63-78).

PARKVALL, M. (1998) "Reassessing the role of demographics in language restructuring”. Comunicação apresentada na conferência Degrees of Restructuring in Creole languages, Regensburg, junho de 1998. PARKVALL, M. (1999) "Afrolex. Lexical africanisms in Atlantic Creoles and related varieties". Ms.

PARKVALL, M. (2000a): "The Alleged Creole Past of Vernacular Brazilian Portuguese”. In: ANDRADE, E. d’, D. PEREIRA \& M. A. 
MOTA (eds.): Crioulos de Base Portuguesa. Lisboa: Associação Portuguesa de Linguística.

PARKVALL, M. (2000b) "Reassessing the role of demographics in language restructuring”. In NEUMANN-HOLZSCHUH, I. \& E. SCHNEIDER (eds). Degrees of Restructuring in Creole Languages. Amsterdam \& Philadelphia: John Benjamins. (195-213).

PARKVALL, M. (2000c) Out of Africa. African influences in Atlantic creoles. London: Battlebridge Publications.

PÉRET, B. (1988) O Quilombo de Palmares. Crónica da "República dos Escravos", Brasil, 1640-1695. Lisboa: Fenda Edições.

PETTER, M. M. Taddoni (1998) "Línguas especiais, línguas secretas: na África e no Brasil”. Revista da ANPOLL 4 (185-201).

QUEIROZ, S. M. (1984) A lingua do negro da costa: um remanescente africano em Bom Despacho (MG). Dissertação de Mestrado, Universidade Federal de Minas Gerais.

REIS, J. J. (1987) Rebelião escrava no Brasil. A história do levante dos malês. 2a ed. São Paulo: Editora Brasiliense.

RÉVAH, I. S. (1963) "La question des substrats et superstrats dans le domaine linguistique brésilien”. Romania 84 (433-50).

RIBEIRO. I: (2002) "Quais as faces do português culto brasileiro?". In ALKMIM, T: M. (org.). (359-81).

RODRIGUES, A. Dall'Igna (1986) Linguas brasileiras. Para o conbecimento das linguas indígenas. São Paulo: Loyola.

RODRIGUES, J. H. (1965) Brazil and Africa. Berkeley \& Los Angeles: University of California Press.

SCHNEIDER, J. (1991) Dictionary of African borrowings in Brazilian Portuguese. Hamburg: Helmut Buske Verlag.

SCHUCHARDT, H. (1888) "Biträge zur Kenntnis des kreolischen Romanisch 1: Allgemeineres über das Negerportugiesische”. Zeitschrift für romanische Philologie 12 (242-54).

SCHWEGLER, A. (1998) "The myth of decreolization: The "strange" case of Palenquero". Comunicação apresentada na conferência Degrees of Restructuring in Creole languages, Regensburg, junho de 1998. 
SERAFIM, C. M. S. (1993) As ilhas do Golfo da Guiné no século XVII (São Tomé, Príncipe e Ano Bom). Dissertação de mestrado, Universidade de Lisboa.

SOUSA, C. B. de (1990) S. Tomé e Principe. Do descobrimento aos meados do século XVI. Desenvolvimento interno e irradiação no Golfo da Guiné. Dissertação de mestrado, Universidade de Lisboa.

SOUZA, A. C. S. (1999) "A variação de concordância de gênero entre o sujeito e o predicativo na linguagem do Cafundó". Estudos Lingüisticos 28 (GEL - Grupo de Estudos Lingüísticos do Estado de São Paulo). Trabalhos apresentados no XLVI Seminário/1998, UNESP - São José do Rio Preto - SP. (208-31).

SPEARS, A. K. \& D. WINFORD (eds.) (1997). The structure and status of pidgins and creoles. Amsterdam: John Benjamins.

TARALLO, F. (1983) Relativization Strategies in Brazilian Portuguese. Tese de doutorado, University of Pennsylvania.

TARALLO, F. (1988) "On the alleged Creole origin of Brazilian Portuguese: untargeted syntactic change". Cadernos de Estudos Lingüisticos 15 (137-61).

TENREIRO, F. (1961) A Ilha de São Tomé. Memórias da Junta de Investigações do Ultramar 24. Lisboa: Junta de investigações do Ultramar. THOGMARTIN, C. O. (1979) "Old Mines, Missouri, et la survivance du français dans la haute vallé du Mississippi”. In VALDMAN, A. \& R. CHAUDENSON (eds). Le français hors de France. Paris: Éditions Honoré Champion. (111-18).

THOMASON, S. G. (1997) “A typology of contact languages". In SPEARS \& WINFORD. (71-88).

THOMASON, S.G \& T. KAUFMAN (1988): Language contact, creoliration, and genetic linguistics. Berkeley: University of California Press. TURNER, J. M. (1970) "Escravos brasileiros no Dahomé". Afro-Ásia 10-11 (5-24).

VOGT, C. \& P. FRY \& M. Gnerre (1980) "Las lenguas secretas de Cafundó”. Punto de vista 3(9:26-32).

VOGT, C. \& P. FRY (1985) “Os mestres da 'língua secreta' do Ca- 
fundó e o paradoxo revelado”. Boletim do Museu Nacional 51:(1-24). VOGT, C. \& P. FRY (1996). Cafundó: A África no Brasil. Campinas: Editora da Unicamp.

VOLKER, C. (1989) "Rabaul Creole German Syntax". University of Hawaii Working Papers in Linguistics 21 (1: 153-89).

WILLIAMS, E. B. (1946) From Latin to Portuguese. Philadelphia: University of Pennsylvania Press.

ZIMMERMANN, K. (1999) 'O português não-padrão falado no Brasil: a tese da variedade pós crioula”. In: ZIMMERMANN, K. (ed) Lenguas criollas de base lexical española y portuguesa. Frankfurt am Main: Verveurt. (441-75).

\section{Notas}

* Este artigo se baseia, em parte, em Parkvall 2000a. Agradecemos Patrícia Ferreira, leitora do Instituto Camões, pela revisão do texto.

1 Nossa tradução.

2 Em artigos posteriores (por exemplo Holm, Lorenzino \& Mello 1999:4), Holm usa uma outra caracterização, admitindo (comunicação pessoal) que os traços incluídos são mais tendências do que traços diagnosticantes.

3 Nossa tradução.

4 Nossa tradução.

5 Sem concordarmos com esse ponto de vista (ver McWhorter \& Parkvall 1999), a nossa impressão é que atualmente este é sustentado pela maioria dos crioulistas.

6 A respeito de casos de simplificações da morfologia verbal do português europeu, ver Révah (1963:444-5) e Melo (1946:113).

7 No português arcaico as taxas de freqüência serão diferentes (Rosa Virgínia Mattos e Silva, comunicação pessoal).

8 Além disso, a importância do elemento africano já foi exagerada, como em Gilbert (1994:5) que levanta "the enormous [sic!] influence of African languages on PBP [=PVB] lexicon".

$9 \mathrm{Na}$ medida em que o léxico possa realmente mostrar características parecidas com as das línguas crioulas, estas se constituiriam, na nossa compreensão do termo crioulo, de traços que pudessem apontar para um ex-pidgin. No entanto, teríamos palavras compostas e transparentes no sentido semântico, como vaca-homem para 'touro', cabelo-pássaro para 'pena', barriga-mão para 'palma’, etc., que são abundantes em vários 
crioulos. Outras estruturas mais analíticas, como interrogativas bi-morfêmicas compostas de uma interrogativa mais um substantivo poderiam fazer parte dos traços lexicais parecidos com aqueles apresentados pelas línguas crioulas.

10 Em Holm (1987:414), mas também utilizado no português europeu, inclusive sem ênfase e sem intervenção com pausa antes da negação pós-verbal (Barme, comunicação pessoal).

11 Em Holm (1987:417, 1992:49). Uma instabilidade semelhante foi constatada no português arcaico (Williams 1946:62-63). Temos que considerar, sobretudo, o fato de um grande número de possíveis substratos, como a maioria das línguas da família banto, incluindo o quicongo, as línguas mais importantes da família kwa, e várias das línguas antigamente classificadas como kwa, também não distinguem as duas consoantes líquidas. Sabemos ainda que nenhuma do PVB até hoje estudada tem excluído uma dessas duas consoantes.

12 Em Holm (1987:419), mas também verificado no português europeu (Mello 1998) e a partir do século XVI, em freqüência básica (Mattos e Silva comunicação pessoal) 13 Em Holm (1987:408), mas cf. Mello (1996:141).

14 Em Holm (1987:420). Por outro lado, McKinney (1982:6) interpreta esses mesmos marcadores de tempo, aspecto e modo como serialização verbal.

15 Holm (1987:421) e (1987:416).

16 O léxico poderia mostrar uma ligação entre o PVB e os crioulos portugueses da África, mas constatamos que o número de vocábulos em comum de origem nãoportuguesa nessas línguas é relativamente baixo, e que os termos que elas têm em comum também aparecem em outros crioulos do Atlântico (e por isso não indicam uma ligação específica entre o PVB e os crioulos portugueses da África Ocidental). Achamos igualmente interessante o fato de as origens dos africanismos brasileiros divergirem significativamente das origens dos africanismos dos crioulos do Golfo do Benim. Dos 102 vocábulos em são-tomense, principense ou annobonese para os quais a bibliografia propõe etimologias africanas, uns 59\% são da família banto, 28\% edo, 6\% iorubá, e 2\% igbo (Parkvall, 1999). Sabemos que um grande número de falantes de quicongo, quimbundo e de iorubá foram levados para o Brasil. O único termo banto de Holm (1987:414), / fuba/, pode ter chegado às ilhas da Guiné e ao Brasil, levado pelos africanos para os dois lugares independentemente um do outro, assim como pode ter acontecido com outros lexemas da família do banto e do iorubá. Se o PVB realmente fosse um descendente dos crioulos da Guiné, deveríamos encontrar não só mais palavras em comum das línguas bantas, mas também um número de palavras com etimologia edo no Brasil. Nesse caso poderíamos sugerir uma ligação genética, já que, pelo que sabemos até hoje, não houve tráfico significativo de falantes de edo para o Brasil. Visto que não temos um corpus 
suficiente de africanismos nas línguas crioulas, e não temos acesso a Schneider (1991), não podemos afirmar com certeza que o PVB e os crioulos do Golfo da Guiné não tenham um maior número de vocábulos de origem edo e comum, mas acreditamos que Holm teria levantado este fato se fosse o caso. Veja-se também Castro (2001) para uma crítica ao dicionário de Schneider.

17 Segundo Castro (1976:22) entre 12000 e 20000 escravos foram trazidos de São Tomé para a Bahia no século XVI.

18 Observe-se que Barbot (1732:361) reproduz a frase "Vos sa Dios” [vós sois Deuses], registrada no Benim em 1682. O verbo copulativo / sa/ ( < P são) é um traço idiossincrático que indica difusão, e sugere uma ligação histórica entre o pidgin português do Benim e o são-tomense.

19 A palatalização é normalmente considerada um fenômeno unidirecional, ou seja, qualquer língua pode mudar $/ \mathrm{tj}, \mathrm{kj} / \mathrm{e} / \mathrm{dj}, \mathrm{gj} / \mathrm{para} / \widetilde{\mathrm{tg}} / \mathrm{e} / \overline{\mathrm{d}} \mathrm{z} /$ mas não vice versa.

20 Holm (1992) chama o dialeto de Helvécia de "crioulo português de Helvécia". Megenney (1993:239) contribui para a confusão terminológica denominando esta variante "Portuguese-based Sprachbund-type Creole with sub-Saharan substrate-induced components".

21 De qualquer maneira, as conclusões tiradas do estudo do dialeto de Helvécia não podem se aplicar a outras localidades no Brasil, já que o input do superstrato em Helvécia não era o de falantes que tinham o português como primeira língua (antes foram francês e alemão).

22 Os dados lingüísticos que temos a respeito de Palmares (sobretudo topônimos e antropônimos) sugerem que a população era predominantemente falante de línguas da família banto. No entanto, sabemos que nem todos os quilombolas eram bantos, e que um dos regentes era falante de ewe (Anderson 1996:559).

23 Vale a pena acrescentar que, assim como foi o caso da perda da marca do plural no PVB acima mencionado, essas reduções não são condicionadas pela fonologia.

24 Note-se porém que a medida utilizada em Parkvall (2000b) foi produzida para quantificar o grau de radicalidade nas variantes do Atlântico, e que não garantimos um bom resultado se esta medida for aplicada a línguas que não tenham surgido do contato entre línguas indo-européias e línguas do tronco Niger-Kongo.

25 Para uma discussão mais detalhada a respeito ver Parkvall (2000b); McWhorter (1999b).

26 Enquanto as colônias britânicas e francesas estão relativamente bem documentadas nesse sentido, o primeiro censo Brasileiro só foi realizado em 1872, e mesmo estimativas anteriores a essa data são raras. Além disso, carecemos de números exatos no que diz respeito aos africanos trazidos para o Brasil, já que o Ministro das Finanças, Rui Barbosa, mandou queimar todos os registros oficiais do tráfico negreiro em 
1891. Talvez por razões econômicas, visto que os proprietários poderiam exigir remuneração, sendo que figurava nos registros o número de escravos que cada um possuía (Castro, 1976:7). No entanto, as avaliações feitas pelos pesquisadores mostram que os africanos e afrodescendentes constituíram mais ou menos dois terços da população do Brasil desde o século XVII até 1890. 